Niniejsza publikacja jest dostępna na licencji Creative Commons. Uznanie autorstwa-Użycie niekomercyjne-Bez utworów zależnych 3.0 Polska. Pewne prawa zastrzeżone na rzecz autora. Zezwala się na wykorzystanie publikacji zgodnie z licencja - pod warunkiem zachowania niniejszej informacji licencyjnej oraz wskazania autora jako właściciela praw do tekstu. Treść licencji jest dostępna na stronie: http://creativecommons.org/licenses/by-nc-nd/3.0/pl/

Lingwistyka Stosowana 20: 5/2016, 63-82

\author{
Magdalena KMIECIK, Małgorzata GUT, \\ Bibianna BALAJ, Jacek MATULEWSKI \\ Uniwersytet Mikołaja Kopernika w Toruniu
}

\title{
Ocena poziomu umiejętności matematycznych na podstawie danych okulograficznych
}

\begin{abstract}
:
The mathematical abilities assessment on the base of oculographic data

Developmental Dyscalculia (DD) is a specific learning disability affecting the acquisition of basic mathematical skills in an otherwise-normal child. As DD prevalence is estimated between 5 and $7 \%$ and it is becoming a serious problem, not only for DD children, but also for their relatives and teachers, there is an urgent need to work on the accurate and reliable methods of diagnosis. Here we present a critical review of some diagnostic tools, both the paper-pencil and computer-assisted ones. Independently on their advantages and disadvantages balance, those methods do not enable to assess the objective markers of cognitive mechanisms being the base of numerical material processing as well as its deficits. The use of eye-tracking, which is a technique useful for study such mechanisms, seems to be an important contribution to dyscalculia diagnosis process. This review presents the results obtained in studies using this method in the investigation of normal and disturbed cognitive processing of numbers.
\end{abstract}

\section{Wstęp}

Dyskalkulia rozwojowa jest zaburzeniem, którego mechanizmy mogą być coraz dokładniej badane. Jednak niejednoznaczna jest jej geneza, co wciąż utrudnia precyzyjną diagnozę. Stosowane testy papierowe i narzędzia komputerowe nie zawsze są miarodajne. Zastosowanie w diagnozie takich technik pomiaru jak eye-tracking otwiera nowe możliwości. Metody obrazowania ruchów oczu dostarczają informacji na temat mechanizmów przetwarzania liczb w różnych formatach, operowania osią liczbową oraz wykonywania działań arytmetycznych. Dzięki temu możliwe jest zrozumienie strategii, które stosują dyskalkulicy w rozwiązywaniu zadań oraz dokładne określenie problemów osób zmagających się z tym zaburzeniem. To natomiast może być podstawą opracowania terapii dobranej do indywidualnych potrzeb osób dotkniętych tym deficytem. 


\section{Zależności numeryczno-przestrzenne}

Badania nad przestrzenną reprezentacją liczb rozpoczęły się już w XIX wieku, kiedy Francis Galton (1880) poprosił osoby badane o przedstawienie ich wyobrażenia liczb. Większość zapytanych mówiła, że wyobraża sobie liczby jako punkty na osi. Odkrycie związku między liczbą i przestrzenią prowadzi do metafory Mentalnej Osi Liczbowej (ang. Mental Number Line - MNL), której dalszą charakterystyką zajął się Frank Restle (1970 za K. Cipora 2013). Aby porównać dwie liczby należy podzielić MNL na tyle części, by każda znalazła się w dwóch różnych obszarach. Stąd wynikać może tzw. efekt dystansu numerycznego - im większa jest odległość między dwiema liczbami na osi liczbowej, tym mniej czasu potrzeba na ich porównanie (zob. L. Cohen/ S. Dehaene/ G. Dehaene-Lambertz 1998). Orientacja przestrzenna Mentalnej Osi Liczbowej zależna jest od kierunku pisania, co zostało potwierdzone istnieniem tzw. efektu SNARC (ang. Spatial-Numerical Association of Response Codes) (S. Dehaene/ S. Bossini/ P. Giraux 1993). Polega on na tym, że osoby wychowujące się w kulturach, w których zapis odbywa się od lewej do prawej strony, szybciej reagują lewą ręką na niższe wartości liczbowe, a na wyższe - prawą. Odwrotnie jest w przypadku kultur, w których zapis odbywa się od strony prawej do lewej (S. Shaki/ M.H. Fischer/ W.M. Petrusic 2009).

\section{Ogólna charakterystyka dyskalkulii}

Umiejętności matematyczne są zależne od szeregu procesów poznawczych (A. Ardila/ M. Rosselli 2002), które często ulegają zaburzeniu wskutek uszkodzenia mózgu. Początkowo uważano, że dyskalkulia to ogólna nazwa dla wszystkich zaburzeń umiejętności matematycznych (R. Shalev/ D. Weirtman/ Z. Amir 1988 za A. Ardila/ M. Rosselli 2002). Jednak dalsza kategoryzacja pozwoliła na rozróżnienie dyskalkulii i akalkulii. Kolejne badania dowiodły, że etiologia tych zaburzeń jest inna: okazało się, że dyskalkulia to szeroko rozumiane zaburzenie rozwojowe, zaś tym związanym z uszkodzeniem mózgu jest akalkulia (A. Ardila/ M. Rosselli 2002).

Prawidłowy przebieg rozwoju umiejętności matematycznych przedstawiono poniżej (L. Kaufmann/ M. von Aster 2012). Jeżeli ich rozwój przebiega wolniej, może to świadczyć o dyskalkulii lub innych zaburzeniach, takich jak dysleksja lub ADHD.

\begin{tabular}{|c|c|}
\hline Procesy poznawcze i okres ich rozwoju & Umiejętności obserwowane u dziecka \\
\hline $\begin{array}{c}\text { Podstawowe umiejętności numeryczne (okres } \\
\text { niemowlęcy, przedszkole) }\end{array}$ & $\begin{array}{c}\text { Rozumienie pojęcia ilości, podstawowe operacje } \\
\text { na małych zbiorach, rozpoznawanie cyfr } \\
\text { arabskich. }\end{array}$ \\
\hline $\begin{array}{c}\text { Wydobywanie wiedzy o faktach matematycznych } \\
\text { (edukacja wczesnoszkolna) }\end{array}$ & $\begin{array}{c}\text { Podstawowe działania na liczbach } \\
\text { jednocyfrowych. }\end{array}$ \\
\hline $\begin{array}{c}\text { Operowanie metodami matematycznymi } \\
\text { póżnejsze klasy szkoły podstawowej, dalsza } \\
\text { edukacja) }\end{array}$ & $\begin{array}{c}\text { Znajomość prawidłowej sekwencji kroków } \\
\text { potrzebnych do rozwiązania zadania } \\
\text { wymagającego wielu obliczeń. }\end{array}$ \\
\hline $\begin{array}{c}\text { Rozumowanie arytmetyczne, } \\
\text { myślenie konceptualne (późniejsze klasy szkoły } \\
\text { podstawowej, dalsza edukacja; umiejętności te są w } \\
\text { dużej mierze zależne od metod nauczania) }\end{array}$ & $\begin{array}{c}\text { Rozumienie skomplikowanych procedur } \\
\text { matematycznych, znajomość podobieństw i różnic } \\
\text { między poszczególnymi rodzajami operacji } \\
\text { matematycznych. }\end{array}$ \\
\hline
\end{tabular}

Tabela 1. Rozwój umiejętności arytmetycznych w trakcie edukacji dziecka (oprac. L. Kaufmann/ M. von Aster 2012). 
Dyskalkulię zaklasyfikowano do grupy specyficznych trudności w uczeniu się (ang. specific learning disorders, SLDs), które sprawiają, że konkretne umiejętności osoby nimi dotkniętej są na znacznie niższym poziomie w porównaniu z rówieśnikami (T. Guillemot 2007). Definicję dyskalkulii rozwojowej jako pierwszy podał L. Košĉ (1982). Jest to zaburzenie w zakresie zdolności matematycznych, czyli predyspozycji do rozumienia procedur matematycznych, posługiwania się nimi w praktyce.

Dyskalkulia bywa czasem traktowana jako „efekt uboczny” lub wręcz odmianę dysleksji, jednak obecnie badacze wskazują na odrębność tych zaburzeń ( B. Wiśniewska/ D. Hulewicz 2007). Dzieci ze współwystępującymi trudnościami w czytaniu i liczeniu mają większe kłopoty $\mathrm{w}$ matematyce $\mathrm{w}$ porównaniu $\mathrm{z}$ dziećmi, które mają problemy arytmetyczne, ale czytają płynnie. U dzieci z tzw. czystą dyskalkulią umiejętności językowe i słuchowe pozostają w granicach normy. Na uwagę zasługuje też relacja między dyskalkulią i ADHD. Ocenia się, że procent dzieci z dyskalkulią, które mają też ADHD waha się w granicach od $15 \%$ do $26 \%$ ( B. Wiśniewska/ D. Hulewicz 2007) podczas gdy u ogółu dzieci wynosi $6-7 \%$. Nie wiadomo też, czy w przypadku dzieci dyskalkulicznych z ADHD można mówić o wielu deficytach, czy o jednym powodującym różne skutki.

Pierwsze objawy obniżonego poziomu umiejętności matematycznych można zaobserwować już u dzieci w wieku przedszkolnym. M.M.M. Mazzocco i R.E. Thompson (2005) odkryli, że dzieci, które osiągają wtedy gorsze wyniki w porównywaniu liczb lub nazywaniu cyfr arabskich, są w znacznie większym stopniu obarczone ryzykiem dyskalkulii w pierwszych latach nauki szkolnej. Najdokładniej opisanym objawem dyskalkulii jest zaburzenie struktury wiedzy o faktach arytmetycznych i procesu jej przywoływania (D.C. Geary 1993; D.C. Geary/ M.K. Howard 2001, L. Kaufmann i in. 2013). U dyskalkulików próby wykonywania obliczeń w oparciu o fakty arytmetyczne przywoływane z pamięci są nieudane. Dzieci z dyskalkulią częściej źle podchodzą do rozwiązania zadania, zaczynają liczyć od końca, co prowadzi do błędnych wyników (K. Landerl/ L. Kaufmann 2013). Ponadto, umiejętnością wyraźnie zaburzoną u dyskalkulików jest szacowanie (B. Butterworth 2003).

\section{Mechanizmy mózgowe}

Badania z użyciem neuroobrazowania wykazały, że neuronalnym podłożem przetwarzania reprezentacji wartości liczbowych jest lewa bruzda śródciemieniowa (ang. intraparietal sulcus, IPS) (S. Dehaene i in. 2003). Wyniki późniejszych badań nie są jednoznaczne. Przetwarzanie liczb okazało się bardziej złożone niż początkowo zakładano i może angażować struktury niezwiązane bezpośrednio z rozumieniem matematyki (K. Landerl/ L. Kaufmann 2013). Na przykład badania interferencji językowej, czyli wpływu języka natywnego na odbiór drugiego języka, przeprowadzone z udziałem grupy zdrowych dorosłych wykazały, że struktury odgrywające rolę w przetwarzaniu materiału językowego ważne są także dla wykonywania dokładnych obliczeń (E.S. Spelke/ S. Tsivkin 2001). Ponadto bruzda śródciemieniowa jest kluczowa przy przetwarzaniu i porównywaniu liczb (K. Landerl/ L. Kaufmann 
2013), a w dokładne obliczenia najbardziej zaangażowane są: lewy zakręt kątowy i kora przedczołowa w lewej półkuli (K. Kucian i in. 2006).

Neuroobrazowanie struktury i organizacji funkcjonalnej mózgu osób zmagających się z dyskalkulią ujawniło pewne nieprawidłowości we wspomnianych obszarach. Price i współpracownicy (G.R. Price/ I. Holloway/ P. Räsänen/ M. Vesterinen/ D. Ansari D. 2007) wykazali, że u dzieci z dyskalkulią aktywacja w tym obszarze w trakcie wykonywania zadań matematycznych jest niższa niż u osób z grupy kontrolnej. Z drugiej strony, dane uzyskane przez K. Kucian i współpracowników (2014) dowiodły, że aktywacja bruzdy śródciemieniowej u osób z trudnościami w zakresie matematyki jest wyraźnie większa. Jedną z potencjalnych przyczyn tych różnic może być fakt, że stopień deficytów funkcjonalnych jest zależny od poziomu trudności zadań i rodzaju wykonywanych czynności (E. Rykhlevskaia/ L.Q. Uddin/ L. Kondos/ V. Menon 2009). Np. pacjenci z uszkodzeniem IPS nie są w stanie poradzić sobie z zadaniami wymagającymi oszacowania wyniku, podczas gdy zadania wymagające działania mnożenia i dzielenia nie sprawiają im problemów.

Badania przeprowadzone z udziałem nastolatków wykazały, że osoby, u których umiejętności matematyczne były poniżej normy, charakteryzowały się bardzo niską gęstością istoty szarej w obszarze płata ciemieniowego (E.B. Isaacs i in. 2001). Z kolei badania mózgów bliźniąt, z których tylko u jednego zdiagnozowano dyskalkulię, wykazały znacznie większą aktywację w obszarze czołowym (zakręcie przedśrodkowym) i w grzbietowej części płata ciemieniowego u tego z dzieci, u którego stwierdzono niższy poziom umiejętności matematycznych. Wyniki takie sugerują, że dzieci te angażują większy obszar mózgu w wykonywanie obliczeń w pamięci, ponieważ procesy te są u nich $\mathrm{w}$ mniejszym stopniu zautomatyzowane niż u zdrowych rówieśników (K. Kucian i in. 2008).

\section{Diagnoza}

\subsection{Metody typu papier-olówek}

Celem diagnozy dyskalkulii jest ocena wszystkich mocnych i słabych stron dziecka w każdym obszarze istotnym dla umiejętności matematycznych i ważnych z punktu widzenia opracowywania odpowiedniej dla niego terapii (K. Landerl/ L. Kaufmann 2013). Gruntowna diagnoza dyskalkulii powinna być przeprowadzona w sposób wielowymiarowy. Poza oceną umiejętności matematycznych, należy też sprawdzić poziom zdolności wzrokowo-przestrzennych i funkcje uwagowe. W ramach kompleksowej diagnozy należy też rozpoznać ewentualne występowanie zaburzeń współtowarzyszących dyskalkulii, np. ADHD lub dysleksji.

Aktualnie do oceny umiejętności matematycznych stosuje się wiele wystandaryzowanych metod (U. Oszwa 2008), np. próby eksperymentalne, oceniające umiejętności posługiwania się liczbami, wykonywania prostych działań oraz znajomości tabliczki mnożenia. Stosowane testy pozwalają na dostosowywanie stopnia trudności zadań do wieku i podstawy programowej. Test Kalkulia III autorstwa Ladislava Košĉa (1982) służy do diagnozowania poziomu umiejętności matematycznych dzieci w wieku 8-15 lat. Zadaniem badanego jest podanie liczby czarnych kropek 
umieszczonych w kwadracie o wymiarach 10x10 jednostek. Poza czarnymi kropkami, w figurze znajdują się też kropki białe, które uczeń powinien pominąć w liczeniu. Układ kropek jest symetryczny, co umożliwia dziecku stosowanie różnych strategii: może je dodawać lub mnożyć. Na podstawie uzyskanych wyników oblicza się wiek matematyczny (WM) dziecka oraz iloraz matematyczny (IM). Interpretacja ilościowa testu Kalkulia III przeprowadzana jest na podstawie czterech tabel. Mimo, że narzędzie to jest powszechnie stosowane w diagnostyce, bardzo łatwo można dostrzec jego wady. Przede wszystkim, test jest bardzo nużący dla dziecka i wymaga od niego ciągłej koncentracji, a dla osób, które mają problemy z czytaniem i rozumieniem instrukcji, bez pomocy terapeuty może być wręcz niewykonalny.

Kolejnym testem opracowanym przez Ladislava Košĉa jest Trójkąt Liczbowy (L. Košĉa 1982). Jego głównym przeznaczeniem jest ocena umiejętności dodawania i poziomu orientacji wzrokowo-przestrzennej. Na początku badany proszony jest o zanotowanie w kolumnie 15 cyfr podawanych przez diagnostę. Następnie dodaje się po dwie cyfry, a wynik każdej z tych operacji zapisywany jest w połowie wysokości między składnikami. Jeżeli wynik dodawania jest liczbą dwucyfrową, to w kolejnej kolumnie należy zapisać jedynie jej cyfrę jedności. W każdej kolejnej kolumnie liczba zapisanych cyfr zmniejsza się więc o jeden w porównaniu z kolumną poprzednią. Zadanie kończy się, kiedy pozostaje tylko jedna cyfra jako wynik dodawania. Prawidłowy zapis przestrzenny powinien przypominać trójkąt. Sprawdzana jest liczba błędów popełnionych w trakcie dodawania i w zapisywaniu sumy. Uzyskany w teście wynik może być podstawą do rozpoznania wąskiego zakresu zaburzeń umiejętności matematycznych, czyli poziomu zautomatyzowania dodawania małych liczb i specyficznego sposobu ich zapisu.

W wielu krajach Europy i Ameryki Północnej stosuje się baterie testów pozwalające na dokładną ocenę umiejętności liczenia, czytania i pisania. British Abilities Scale (BAS) to zestaw zadań przeznaczony dla dzieci w wieku 6-17 lat (S. Parsons 2006), jednak diagnozowane są już nim nawet pięciolatki. W skład BAS wchodzi kilkanaście testów, które tworzą trzy podkategorie: skale zasadnicze (definiowanie słów, rozumowanie matematyczne, pamięć obiektów), skale dydaktyczne (pamięć cyfr, rozpoznawanie obrazków, szybkość przetwarzania informacji) i skale osiągnięć (pomiar umiejętności matematycznych, znajomości ortografii i czytania słów). Bateria ta pozwala na dokładną diagnozę i ocenę tego, jak badane dziecko wypada na tle grupy. Na podstawie uzyskanych wyników można też przewidzieć ścieżkę rozwoju dziecka i indywidualnie dobrać odpowiednie ćwiczenia. Niestety, skala ta jest dostosowana jedynie do brytyjskiego systemu nauczania, zatem stosowanie jej w innych krajach nie przyniesie pożądanych skutków.

Kwestionariusz Operowania Liczbami (Numeracy Questionnaire) D. Ansari (2002 za U. Oszwa 2008) został skonstruowany w celu wstępnej diagnozy trudności w zakresie umiejętności matematycznych. Narzędzie wykorzystuje informacje, których udzielić mogą rodzice dziecka lub uczący go nauczyciele. Składa się z 52 pytań wymagających zaznaczenia odpowiedzi na skali: jeśli dziecko nie umie wykonać danej czynności należy zaznaczyć „,0”, jeśli wykonuje czasem - „,5”, a gdy potrafi należy zakreślić „10”. Pytania zostały przyporządkowane do czterech kategorii: 
sprawdzenie znajomości pojęcia liczby i umiejętności liczenia, ocena umiejętności posługiwania się liczbami w życiu codziennym, radzenie sobie z prostymi zadaniami rachunkowymi oraz wyniki osiągane w szkole na lekcjach matematyki. Na podstawie tego kwestionariusza Ansari i współpracownicy stworzyli test dla dzieci z trudnościami w zakresie umiejętności matematycznych - Numeracy Screener (N. Nosworthy $i$ in. 2013). Rozwiązanie testu zajmuje bardzo mało czasu, a zadaniem dziecka jest porównywanie wielkości liczbowych w formatach symbolicznych i niesymoblicznych. Autorzy zaznaczają jednak, że nie jest to test przeznaczony do diagnozowania dyskalkulii. Służy on jedynie do określania słabych i mocnych stron ucznia w zakresie matematyki.

Skala Umiejętności Matematycznych U. Oszwy (2006) została dostosowana do programu nauczania matematyki obowiązującego w Polsce i sprawdza poziom umiejętności matematycznych dzieci w wieku 7-8 lat. Bateria obejmuje 70 pytań, które dotyczą wszystkich obszarów operowania materiałem liczbowym. Obserwacji i oceny tych umiejętności dokonuje nauczyciel. Na pytania należy odpowiadać „tak” lub „nie”, a w razie wątpliwości wybrać odpowiedź bliższą prawdzie. Jeśli istnieje taka konieczność, można zaaranżować sytuację eksperymentalną, aby sprawdzić, jak dziecko poradzi sobie z określonym problemem. Zastosowanie tej skali wymaga od nauczyciela znajomości ucznia i powinno być poprzedzone wnikliwymi obserwacjami jego zachowań i myślenia w działaniu.

Skala Gotowości Matematycznej i Ryzyka Dyskalkulii (SGMiRD), autorstwa Elżbiety Karpińskiej, Urszuli Sajewicz-Radtke i Bartosza Radtke (E. Karpińska i in. 2014), to narzędzie pozwalające ocenić poziom kompetencji matematycznych dziecka, jego gotowość matematyczną oraz ryzyko wystąpienia dyskalkulii. Bateria obejmuje osiemnaście wieloaspektowych zadań sprawdzających m.in. myślenie operacyjne, zdolność postrzegania stałości przedmiotu, znajomość cyfr i znaków matematycznych czy umiejętność przeliczania i szacowania.

W kontekście diagnozy poziomu kompetencji matematycznych poza oceną umiejętności radzenia sobie z zadaniami matematycznymi, bardzo ważna jest również ocena poziomu integracji informacji wzrokowo-przestrzennych (A. Ardila/ M. Rosselli 2002). W Polsce w tym celu używa się testu Figury Złożonej Raya (FZR). Test ten jest powszechnie stosowany w diagnostyce neuropsychologicznej (P. Przybylski/ U. Oszwa 2007). Badany proszony jest o wykonanie jak najdokładniejszej kopii FZR. Dziecko może zmieniać ułożenie kartki, aby jego rysunek był możliwie najlepszy. Oceny poziomu rozwoju funkcji wzrokowo-przestrzennych dokonuje się poprzez odniesienie wyniku surowego do norm dla określonego przedziału wiekowego.

Mimo tak szerokiej gamy testów, jakie można zastosować do diagnozowania dyskalkulii, nadal istnieje zapotrzebowanie na tworzenie dokładniejszych narzędzi. B. Adler opracował kompleksową metodę diagnozy dyskalkulii składającą się z trzech testów: neuropsychologicznego, neuropediatrycznego i neuropedagogicznego (zob. B. Wiśniewska/ D. Hulewicz 2007). W pierwszym etapie diagnozy rozwiązywany jest test neuropedagogiczny. Sprawdza, w jaki sposób uczeń radzi sobie z informacją, werbalną i wzrokowo-przestrzenną, czy dziecko jest w stanie samo- 
dzielnie rozwiązać zadanie, czy potrzebuje pomocy w formie rysunków oraz w jaki sposób podchodzi do rozwiązania zadań matematycznych. Test jest przygotowywany przez nauczyciela we współpracy z rodzicami, wychowawcą i psychologiem. Kolejnym etapem jest przeprowadzenie testu neuropsychologicznego. Tym razem ocenie podlega osobowość i rozwój poznawczy. Jak podkreśla B. Adler (2001), ocena rozwoju poznawczego może być kluczowym elementem diagnozy dyskalkulii, ponieważ pozwala stwierdzić, czy inne umiejętności (tj. językowe, artystyczne) są na poziomie adekwatnym do wieku badanego. Ostatnim, trzecim etapem jest test neuropediatryczny sprawdzający ogólny stan zdrowia dziecka. Przeprowadza go pediatra lub neurolog, aby sprawdzić, jak dziecko zachowuje się w naturalnym dla siebie środowisku. Lekarz musi się także zapoznać $\mathrm{z}$ historią przebytych chorób, aby wyeliminować choroby neurologiczne, które mogą być podłożem trudności w matematyce. Celem takiego badania jest dokładne określenie trudności dziecka oraz wybranie odpowiedniej terapii.

Powyżej opisane narzędzia nie są pozbawione wad. Metody te nie dostarczają dokładnej informacji na temat czasu i dokładności udzielanej przez dziecko odpowiedzi (J. Mazzeo i in. 1991). Zmienne te mogą być pomocne przy precyzyjnym określaniu trudności w zakresie matematyki. Ponadto, umieszczone w teście pytania bywają niewłaściwe skonstruowane, przez co mogą niewystarczająco wiarygodnie sprawdzać procesy poznawcze. Badany może więc nie rozumieć ich treści, co prowadzi do błędnych odpowiedzi. Na przykład, dziecko poproszone o policzenie, ile biedronek znajduje się na każdym z przedstawionych na obrazku liści, może podać ich łączną liczbę. Po drugie, nieodpowiednio sformułowane pytania utrwalają błędne myślenie o rozwiązywaniu zadań matematycznych u dzieci lub nauczycieli, którzy są mniej kompetentni (K.K.J Yeo 2006). Należy też pamiętać, że testy papierowe składają się z bardzo małej liczby próbek, a kolejność ich wykonywania nie zmienia się. Oznacza to, że ich rozkład może być zapamiętany przez ucznia. Rozwiązywanie testu na kartce jest też bardzo monotonne, przez co może się wydać badanemu mało atrakcyjne i zniechęcić go do pracy.

\subsection{Metody komputerowe}

Wraz z rozwojem technologii zaczęto modyfikować testy diagnostyczne oraz projektować narzędzia komputerowe, które stają się coraz bardziej powszechne. W trakcie wykonywania zadań, odpowiedzi udziela się najczęściej poprzez naciśnięcie właściwego klawisza na klawiaturze komputera, konsoli lub myszy. Komputer może poprawić wiarygodność badania dzięki automatycznej adaptacji testu do umiejętności dziecka.

Metody diagnozy nie są jednak rozwijane w sposób równomierny na całym świecie. Jednym z pierwszych narzędzi komputerowych do diagnozowania dyskalkulii jest opracowany przez B. Butterwortha (2003) „Dyscalculia Screener”. W procesie tworzenia tego testu wyodrębniono najbardziej miarodajne zadania. Uczeń reaguje poprzez naciśnięcie odpowiedniego klawisza na klawiaturze, a odpowiedź jest natychmiast analizowana przez komputer. 
W pierwszym zadaniu badany jest czas reakcji prostej. Kolejnym zadaniem jest porównywanie liczby kropek $\mathrm{z}$ liczbą zapisaną $\mathrm{w}$ formacie symbolicznym. B. Butterworth podkreśla, że to zadanie jest dość proste i prawdopodobnie zarówno dzieci z trudnościami w zakresie matematyki, jak i te osiągające dobre wyniki udzielą poprawnej odpowiedzi w większości próbek. Dzieci bez takich trudności odpowiedzą jednak szybciej, ponieważ ich umiejętności są lepiej usystematyzowane. Trzecim zadaniem jest Stroop numeryczny, w którym porównywane są dwie liczby, jednak w niektórych próbach liczby te różnią się wielkością fizyczną. W czwartym, ostatnim, zadaniu dziecko proszone jest o zweryfikowanie poprawności wyniku działania prezentowanego na ekranie. W wersji testu dla młodszych dzieci, uczniowie oceniają jedynie rezultat dodawania, natomiast dzieci powyżej 10. roku życia sprawdzają też wynik mnożenia. Również w tym przypadku można sądzić, że większość dzieci udzieli poprawnej odpowiedzi, dlatego bardzo ważny jest czas, którego potrzebują, aby odpowiedzieć właściwie. Wyniki z całego testu odnoszone są do wystandaryzowanych skal, które są automatycznie przetwarzane przez komputer. Test ten przeznaczony jest głównie do diagnozowania ryzyka dyskalkulii. Nie skupia się natomiast na ocenie osiągnięć ucznia $\mathrm{w}$ dziedzinie matematyki.

B. Cangöz i współpracownicy zaprojektowali narzędzie przeznaczone do diagnozy dla dzieci w wieku 6-9 lat, w którym wyodrębnili i opisali pięć zadań, których używanie $w$ diagnostyce wspomaganej komputerowo jest najbardziej miarodajne (zob. B. Cangöz 2013). Test jest obsługiwany przy użyciu tabletów z oprogramowaniem typu Android. Zdaniem badaczy, korzystanie z nich w trakcie diagnozy jest łatwiejsze ze względu na ich mały rozmiar i wagę. Dzięki temu dotarcie do szkół z testem staje się prostsze.

Składa się on z dwóch części: próbnej i właściwej. W części testowej badani zapoznają się z formą zadań i ćwiczą udzielanie odpowiedzi. Część właściwa składa się z dwóch prób, każda trwa pół godziny. Badany odpowiada zaznaczając poprawną odpowiedź na ekranie tabletu. W pierwszym zadaniu dziecko proszone jest o podanie liczby kropek prezentowanych na ekranie w figurach geometrycznych. Następnym zadaniem jest Stroop numeryczny, opisany już przez B. Butterwortha. Kolejnym jest oszacowanie liczebności przedmiotów pojawiających się na obrazku. $\mathrm{Na}$ koniec dziecko proszone jest o zaznaczenie pozycji liczby na osi liczbowej bez podziałki oraz wykonanie prostych działań arytmetycznych.

W Polsce stworzono Test Oceny Behawioralnych Wskaźników Umysłowych Reprezentacji Liczb i Ryzyka Dyskalkulii Prokalkulia 6-9 (M. Gut/ Ł. Goraczewski/ J. Matulewski 2016, M. Gut i in. 2016), przeznaczony do oceny poziomu podstawowych umiejętności matematycznych u dzieci w wieku 6 -9 lat. Jego konstrukcja jest podobna do opisanych wyżej narzędzi. W pierwszym zadaniu badany jest czas reakcji prostej. Następnie, zadaniem dziecka jest możliwie jak najszybsze wskazanie większej liczby z dwóch prezentowanych na ekranie poprzez naciśnięcie odpowiedniego klawisza na klawiaturze komputerowej. Liczby prezentowane są w różnych formatach: w postaci cyfr arabskich oraz kropek różnej wielkości. Kolejne zadania to Stroop numeryczny oraz zadanie pozwalające ocenić umiejętność szacowania. W drugiej części dziecko musi zaznaczyć położenie liczby (również prezentowanej w 
różnych formatach) na osi liczbowej z podziałką i bez niej. Wykonanie testu trwa około pół godziny. Celem stosowania narzędzia jest ocena czasu reakcji i dokładności udzielanych przez dziecko odpowiedzi.

Metody komputerowe pozwalają na dokładniejszą ocenę umiejętności matematycznych. Komputer szybko oblicza poprawność odpowiedzi i precyzyjnie mierzy czas potrzebny do jej udzielenia. Informacje te mogą być bardzo ważne przy rozpoznawaniu dzieci z trudnościami w zakresie matematyki wśród tych, które takich problemów nie mają. Dodatkowym atutem tej formy diagnozy jest możliwość przetwarzania danych przez komputer, co d oszczędza czas i pracę diagnosty. Ponadto, $\mathrm{w}$ tej formie diagnozy zadania mogą być złożone $\mathrm{z}$ większej liczby prób, przez co otrzymany wynik jest bardziej wiarygodny. Rozwiązywanie testu na komputerze jest dla dzieci formą zabawy i alternatywą dla nudnych zadań na kartce. Samo rozpowszechnianie testu również jest łatwiejsze, ponieważ nie wymaga drukowania wielokartkowych arkuszy odpowiedzi i obszernych instrukcji. Dodatkowo, wyniki badanych również przechowywane są na komputerze, dzięki czemu możliwy jest łatwy do nich dostęp i lepsza organizacja bazy danych.

Sceptycy dopatrują się jednak w diagnostyce komputerowej pewnych wad (J.L. Singleton 2004). Mianowicie, obserwator lub terapeuta ma tę przewagę nad programem komputerowym, że dostrzega aspekty, na których oprogramowanie się nie skupia. W szczególności dotyczy to niektórych zachowań społecznych i emocjonalnych, które mogą świadczyć o zaburzeniach (np. ADHD), a także o ogólnym stanie zdrowia osoby badanej.

\section{Ruchy gałek ocznych podczas przetwarzania liczb}

Wykorzystywanie eye-trackingu w badaniach funkcji poznawczych jest bardzo użyteczne ze względu na dwa efekty znane z badań $z$ wykorzystaniem tej metody. Po pierwsze, patrzenie na jakiś obiekt sugeruje, że jest to przedmiot, o którym aktualnie myślimy (M.K. Tanenhaus i in. 1995). Po drugie, wiadomo, że im dłużej wpatrujemy się w obiekt, tym więcej uwagi mu poświęcamy (zob. M.A. Just/ P.A. Carpenter 1980). Biorąc to pod uwagę, można przyjąć, że śledzenie fiksacji oka pozwala na dokładniejsze badanie procesów poznawczych, a także poznanie strategii stosowanych do rozwiązywania zadań (J. Mock i in. 2016). Jednakże, zastosowanie eyetrackingu $\mathrm{w}$ badaniach dotyczących przetwarzania liczb jest znacznie mniej popularne niż w badaniach koncentrujących się np. na umiejętnościach czytania.

\subsection{Przetwarzanie liczb w formacie niesymbolicznym}

Pod koniec XIX wieku uważano, że dokładność liczenia jest ograniczona przez małą liczbę dobrowolnych sakkad (zob. E. Landolt 1897, za: J. Mock i in. 2015), czyli mimowolnych ruchów oka w których punkt spojrzenia znacząco zmienia pozycję. Podczas obserwacji sakkady następują przy przerzucaniu uwagi pomiędzy obserwowanymi detalami obiektu. E. Kolwer i R.M. Steinmann (1977) sprawdzili tę hipotezę. Zbadali oni dokładność w trakcie liczenia kresek tworzących powtarzalne wzory oraz kropek, które usytuowane były w sposób losowy. Okazało się, że w przy- 
padku wzorów z kresek dokładność liczenia nie jest zależna od liczby ruchów sakkadowych. Jednakże, w przypadku losowo rozmieszczonych kropek, liczba sakkad korelowała dodatnio z poprawnością odpowiedzi.

Badania nad przetwarzaniem liczb prowadzone są nie tylko $\mathrm{z}$ udziałem osób $\mathrm{w}$ wieku szkolnym lub pełnoletnich, ale także w okresie niemowlęcym. Szczególnie interesujące jest identyfikowanie liczby elementów w małych zbiorach (ang. subitizing). C. Sophian i M.E. Crosby (2008) zbadali przy użyciu eye-trackera poziom zautomatyzowania tej umiejętności poprzez ocenę procesów przed-uwagowych i uwagowych w zadaniu wyliczania. Biorący udział w badaniu dorośli proszeni byli o podanie liczby strzałek, których grot skierowany był do dołu ekranu. Każdy uczestnik rozwiązywał zadanie $\mathrm{w}$ trzech warunkach eksperymentalnych: w pierwszym przypadku na ekranie nie pojawiały się dystraktory, natomiast w kolejnych dwóch na ekranie pojawiały się odpowiednio ukośne i pionowe linie, które miały rozproszyć uwagę badanego. Uzyskane dane wykazały, że najwięcej fiksacji odnotowano w pierwszym przypadku (bez dystraktorów), kiedy liczba strzałek skierowanych do dołu przekraczała 4. Jest to zgodne z założeniem, że człowiek jest wstanie automatycznie identyfikować małe zbiory elementów. Kiedy liczba elementów rośnie, potrzeba więcej czasu, aby ją zweryfikować, przez co rośnie czas fiksacji wzroku na zbiorze. Podobnych obserwacji nie poczyniono na podstawie analizy danych uzyskanych w drugim warunku eksperymentalnym.

W celu dookreślenia granicy między oszacowaniem liczebności małych zbiorów a umiejętnością przetwarzania elementów większych zbiorów przebadano 9miesięczne niemowlęta (A. Ceulemans i in. 2014). Prezentowali oni dzieciom obrazki, na których parami przedstawiano zestawy kropek. Na jednym obrazku była jedna kropka i cztery kropki, a na drugim - cztery kropki i osiem kropek. Analiza czasu i długości fiksacji wykazała, że dzieci poprawnie odróżniały jedną kropkę od czterech, ale nie radziły sobie z drugą parą bodźców. Dane oko-ruchowe potwierdziły, że określanie liczebności małych zbiorów i zliczanie większych grup elementów angażują inne procesy wyliczania. Rozróżnianie elementów do czterech następuje w sposób całościowy, natomiast większe zbiory przetwarzane są sekwencyjnie.

\subsection{Przetwarzanie liczb $w$ formacie symbolicznym}

Procesy postrzegania liczb można podzielić na te związane z percepcją cyfry jako informacji numerycznej w wieku wczesnoszkolnym oraz odczytywanie liczb wielocyfrowych w latach późniejszych (S. Deheane/ L. Cohen 1995). W związku z tym, badano podstawowy aspekt percepcyjny liczb symbolicznych: szybkość przetwarzania cyfr i czas ich detekcji. M. Milosavljevic i współpracownicy zainteresowali się przetwarzaniem liczb w trakcie porównywania ich parami (M. Milosavljevic i in. 2011). Sprawdzili oni maksymalną prędkość, z jaką człowiek może porównać dwie jednocyfrowe liczby za pomocą ruchów sakkadowych w prawo lub lewo. Uzyskany wynik (306 ms) sugeruje, że w mózgu zachodzą procesy zaangażowane w porównywanie jednocyfrowych liczb i równolegle mogą być one związane z przetwarzaniem cech fizycznych liczby. Rezultat ten jest zgodny z poprzednimi odkryciami, z których wiadomo, że człowiek potrzebuje około $370 \mathrm{~ms}$ na porównanie liczb znaj- 
dujących się w bliskim położeniu względem siebie na osi liczbowej, a $390 \mathrm{~ms}$ na rozróżnienie tych leżących daleko od siebie (S. Dehaene, 1996). Ponadto J.-H. Song i K. Nakayama (2008) oszacowali czas potrzebny na porównanie liczb, które oddalone są od siebie o jedną lub o cztery pozycje na osi. Analiza uzyskanych danych wykazała, że w pierwszym przypadku jest to okres $338 \mathrm{~ms}$, natomiast w drugim warunku eksperymentalnym zmniejsza się on do $313 \mathrm{~ms}$.

Czas potrzebny na przetworzenie liczby w formacie symbolicznym zależny jest od liczby sylab, która występuje w jej nazwie (J. Pynte 1974). I. Gielen i współpracownicy dowiedli jednak, że liczba sylab ma znaczenie tylko wtedy, kiedy zadaniem badanego jest przypominanie sobie liczb(zob. I. Gielen i in. 1991). Natomiast, kiedy zadaniem badanego była ocena, czy środkowa cyfra $\mathrm{z}$ prezentowanej trzycyfrowej liczby jest średnią arytmetyczną dwóch pozostałych, to długość sylab nie wpływała na czas przetwarzania liczb. M. Brysbaert (1995) z kolei odkrył, że rozpoznanie liczby jest ułatwione poprzez uprzednie przetworzenie liczby znajdującej się w jej bliskim sąsiedztwie na mentalnej osi liczbowej. Ponadto, wzrost czasu potrzebnego do odczytania danej liczby może mieć związek z częstotliwością jej występowania. Im częściej ona występuje, tym szybciej jest rozpoznawana.

Przetwarzanie liczb wielocyfrowych jest bardziej złożonym procesem (zob. T. Dackermann i in. 2015). H.-C. Nuerk i K. Moeller (2011) wyodrębnili trzy modele przetwarzania tych wielkości liczbowych. Pierwszy z nich mówi o przetwarzaniu całościowym. W tym przypadku liczba odbierana jest jako integralna całość, nie ma potrzeby „rozbijania” jej na cyfry składowe (S. Dehaene/ E. Dupoux/ J. Mehle 1990). Odwrotna sytuacja zachodzi w przypadku przetwarzania sekwencyjnego: tutaj liczby rozkładane są na budujące je ,atomy”, osobno analizowane są cyfry tysięcy i setek (S.E. Poltrock/ D.R. Schwarz 1984). Osoba posługująca się trzecim rodzajem strategii (zgodnym z trzecim modelem) przetwarzania równoległego przyrównuje jednocześnie wartość każdej cyfry do wartości cyfry znajdującej się obok (H.-C. Nuerk/ K. Willmes 2005). Jednakże zauważono, że całościowe przetwarzanie liczb cztero-, pięcio- i sześciocyfrowych nie jest możliwe (Bahnmueller i in. 2015). Liczby te są po prostu za duże, zatem są przetwarzane w sposób sekwencyjny (M. Korvorst/ M.F. Damian 2008).

Ruchy gałek ocznych odzwierciedlają powyższe strategie (K. Moeller 2009). W przypadku przetwarzania całościowego średnia liczba fiksacji, czyli utrzymywanie oka na takiej pozycji, aby obraz padał na plamkę żółtą, jest taka sama dla każdej cyfry. Liczby odbierane są zatem jako całość. W przetwarzaniu równoległym najwięcej fiksacji odnotowano przy pierwszej cyfrze, a wraz z kolejnymi cyframi jest ich coraz mniej. W przypadku przetwarzania sekwencyjnego nie odnotowano prawie żadnych fiksacji poza pierwszą cyfrą. Reszta była przez badanego pomijana.

\subsection{Ruchy gałek ocznych w trakcie rozwiązywania zadań arytmetycznych}

\subsubsection{Relacje między liczbą a przestrzenią}

Badania relacji między przestrzenią a liczbą zostały rozszerzone o arytmetykę na liczbach niesymbolicznych (zob. X. Liang i in. 2016). Jednym z dowodów na zaan- 
gażowanie mentalnej osi liczbowej w działania arytmetyczne jest istnienie tzw. efektu pędu operacyjnego (ang. operational momentum, OM). K. McCrink, S. Dehaene i G. Dehaene-Lambertz (2007) prezentowali badanym krótkie filmy, w których prezentowane obiekty były do siebie dodawane lub od siebie odejmowane. Zadaniem uczestników było oszacowanie, czy prezentowany wynik jest poprawny. W przypadku dodawania szacowany wynik zwykle przewyższał poprawną odpowiedź. Odwrotna sytuacja zachodziła, kiedy prezentowano odejmowanie. Wtedy badani wybierali znacznie niższą liczbę niż docelowa.

Istnienie efektu OM zostało także potwierdzone w odniesieniu do działań arytmetycznych na cyfrach arabskich (M. Pinhas/ M.H. Fischer 2008). Badanym prezentowano działania dodawania i odejmowania oraz poziomą oś liczbową z zaznaczonymi pozycjami liczb 0 i 10 . Zadaniem uczestników było obliczenie oraz zaznaczenie poprawnej odpowiedzi na osi. Okazało się, że kiedy badani rozwiązywali działanie $4+2$, to zaznaczali odpowiedź bliżej prawego krańca osi (w stosunku do właściwego miejsca) niż właściwa pozycja wyniku „6”, natomiast kiedy typowali wynik działania 8-2, to umieszczali go bardziej z lewej strony. Zjawisko to wystąpiło nawet wtedy, kiedy drugim elementem działania była cyfra 0 .

Czego o tym efekcie można się dodatkowo dowiedzieć śledząc ruchy oczu? M. Hartmann, F.W. Mast i M.H. Fischer (2015) sprawdzili, w jaki sposób efekt OM łączy się z ruchami gałek oczu w trakcie wykonywania działań. Badacze oczekiwali, że dodawanie będzie wywoływało przesunięcie uwagi w prawo lub do góry, natomiast odejmowanie - w lewo lub na dół. Celem była ocena preferencji przestrzennych $\mathrm{w}$ trakcie wykonywania działań matematycznych w pamięci. Zadaniem badanych było wypowiedzenie wyniku na głos. W trakcie całego testu patrzyli oni na pusty ekran. Analizy danych eye-trackerowych nie wykazały w tym przypadku różnic $\mathrm{w}$ poziomym położeniu spojrzenia, natomiast $\mathrm{w}$ przypadku dodawania odnotowano przesunięcie wzroku do góry w porównaniu z odejmowaniem. Różnica ta była spowodowana wpływem operatora działania, a nie procesem obliczeniowym. Wyniki te potwierdzają semantyczny związek między liczbą a przestrzenią.

\subsubsection{Strategie liczenia}

W trakcie rozwiązywania zadań ludzie posługują się różnymi typami strategii (zob. tab. 2; L. Kaufmann/ M. von Aster 2012). Pomiar ruchów oczu pozwala na dookreślenie tych strategii i zrozumienie procesów obliczeniowych (zob. J. Mock/ S. Huber/ E. Klein/ K. Moeller 2016). Wyniki uzyskane z pierwszego badania z wykorzystaniem eye-trackingu niestety nie pozwoliły na wyciągnięcie jednoznacznych wniosków (P. Suppes i in. 1983). Jednakże, autorzy sformułowali teorię dotyczącą czterech typów ruchów oczu w trakcie wykonywania zadań: patrzenie na kolejny symbol (ang. forward), patrzenie w jeden punkt (stayput), powracanie do poprzedniej liczby (backtracking) oraz omijanie liczby i przechodzenie do kolejnej (skipping). P. Suppes i współpracownicy uznali jednak tę teorię za mało dokładną (ibid.). 


\begin{tabular}{|c|c|}
\hline Strategia & Przykład strategii użyty do rozwiązania działania $6+4$ \\
\hline Sumowanie bezpośrednie & $6+4=10$ \\
\hline & $1+1+1+1+1+1=6$ \\
Zliczanie wszystkich elementów & $1+1+1+1=4$ \\
& $6+4=10$ \\
\hline & $6+1=7$ \\
Dodawanie do pierwszego składnika & $7+1=8$ \\
& $8+1=9$ \\
& $9+1=10$ \\
\hline \multirow{2}{*}{ Rozbijanie działania na komponenty } & $5+4=9$ \\
& $9+1=10$ \\
\hline Rozbijanie działania na poszczególne kroki & $(6-1)+(4+1)=5+5=10$ \\
\hline
\end{tabular}

Tabela 2. Przyktady strategii stosowanych

w trakcie wykonywania działań matematycznych; zob. L. Kaufmann/M. von Aster 2012).

Pewne różnice w ruchach gałek ocznych dorosłych i dzieci w trakcie rozwiązywania zadań zaobserwowali K. Moeller, E. Klein i H.-C. Nuerk (2011). Dzieci podczas liczenia skupiały swój wzrok na liczbie dziesiątek danej liczby, natomiast dorośli koncentrowali się na analizowaniu liczby jedności. W innych badaniach sprawdzono, jak treść zadań wpływa na poprawność ich wykonania. Zaobserwowano, że dzieci znacznie dłużej skupiały wzrok na poleceniu, kiedy zadanie było bardziej skomplikowane. Uczniowie, których poziom umiejętności był nieco niższy, kilkakrotnie przerzucali wzrok z treści na działanie.

Celem sprawdzenia, który znak matematyczny szybciej przykuwa uwagę, D.H. Landy i współpracownicy (zob. D.H. Landy i in. 2008) prezentowali badanym działania mieszane. Uczestnicy badania zostali poproszeni o rozwiązanie prostego zadania $2 \times 3+4$. Dodatkowo, modyfikowano odstęp pomiędzy znakami. Analizując dane eye-trackerowe wykazano, że badani najszybciej skupiali swój wzrok na znaku mnożenia, kiedy był usytuowany blisko cyfr. Oznacza to, że mały odstęp między liczbami i znak mnożenia podobnie angażują uwagę. Podobne badanie przeprowadzili E. Schneider, M. Maruyama, S. Dehaene i M. Sigman (zob. E. Schneider i in. 2012). Sprawdzili, w jaki sposób składnia działania wpływa na poprawność odpowiedzi. Badacze przedstawili uczestnikom zapisy działań matematycznych z wieloma nawiasami po lewej lub prawej stronie. Niezależnie od umiejscowienia nawiasów, wszyscy badani najpierw skupiali wzrok po lewej stronie działania. Jednakże, w przypadku, kiedy skomplikowane działanie było po stronie prawej, szybko przenosili wzrok na tę część, która powinna zostać wykonana jako pierwsza. W kolejnej próbie badacze wzbogacili swoje badanie o działania, w których wiele nawiasów było umieszczone w środku. Otrzymany wynik był analogiczny do tego z poprzedniej wersji eksperymentu. Oznacza to, że trudniejsze zadania są rozwiązywane wolniej, jednak nie wymagają większej liczby fiksacji. Zaobserwowano także, że liczba fiksacji zależna jest od złożoności działania, zaś czas ich trwania zależy od wielkości liczb. Obserwacja ta sugeruje, że rozwiązywanie problemów arytmetycznych może być zapisywane w prosty sposób, w którym jedna fiksacja odpowiada jednej operacji. 


\subsubsection{Przetwarzanie osi liczbowej}

Zadania z osią liczbową, na której zaznaczono jedynie pierwszą i ostatnią liczbę, pozwalają łatwo sprawdzić przestrzenne reprezentacje wielkości liczbowych (R.S. Siegler/ J.E. Opfer 2003). J.L. Sullivan i współpracownicy (J.L. Sullivan i in. 2011) analizowali strategie stosowane przez dorosłych w trakcie rozwiązywania zadania $\mathrm{z}$ szacowaniem pozycji liczby na osi liczbowej. Autorzy zauważyli, że badani najpierw skupiali wzrok na możliwych punktach odniesienia, czyli na początku, na końcu i na środku osi. Ostateczne zaznaczenie pozycji liczby było poprzedzone długą fiksacją w pobliżu wybranej lokalizacji. Ponadto, zauważono, że kierunek pierwszej fiksacji był zależny od wielkości liczby - jeśli badani mieli do czynienia z mniejszą liczbą, najpierw kierowali wzrok na lewo. W przypadku, gdy prezentowana liczba była większa, patrzyli oni na prawo. Wskazuje to na dokładną transformację liczby na przestrzeń. We wcześniejszych badaniach M. Schneider i współpracownicy (M. Schneider i in. 2008) sprawdzili, jak z tego typu zadaniami radzą sobie dzieci $\mathrm{w}$ pierwszych latach szkoły podstawowej. Badacze zaobserwowali, że wraz ze wzrostem wiedzy spowodowanym przejściem do kolejnej klasy, dzieci częściej skupiają wzrok w miejscu poprawnego położenia liczby. Dzieci ze wszystkich klas skupiały też wzrok na początku, na końcu i na środku osi. Młodsi uczniowie rzadziej patrzyli jednak na prawą stronę, co prawdopodobnie było spowodowane nieznajomością większych liczb. Uzyskane wyniki sugerują, że wzory ścieżek wzrokowych odzwierciedlają rozwój kompetencji matematycznych u dzieci w wieku szkolnym.

\subsubsection{Badania z udziałem dyskalkulików}

Wykorzystywanie zapisu ruchów gałek ocznych w trakcie wykonywania zadań z osią liczbową jako narzędzia diagnozującego trudności matematyczne, może dostarczyć wielu informacji o procesach przetwarzania informacji liczbowej oraz o towarzyszących im deficytach (S. van Viersen i in. 2013). Fakt, że dane okoruchowe odzwierciedlają rozwój mentalnej osi liczbowej jest szczególnie interesujący dla badaczy zajmujących się dziećmi z dyskalkulią (J. Mock i in. 2015). Odpowiedzi udzielane przez tę grupę w zadaniach $\mathrm{z}$ szacowaniem pozycji liczby na osi są najmniej dokładne (J. E. van't Noordende i in. 2016). Nieznane są jednak powody tych trudności. Wykazano różnice w strategiach szacowania stosowanych przez dzieci z trudnościami w zakresie matematycki i tymi, które rozwijają się prawidłowo (J.E. van't Noordende/ M.E. Kolkmann 2013 za: J.E. van't Noordende i in. 2016). Zadaniem uczniów było wyznaczenie pozycji liczby na osi. Mogli w tym celu wspomóc się punktem odniesienia, który usytuowany był na środku osi. Zgodnie z przypuszczeniami badaczy, dzieci z trudnościami rzadziej korzystały z punktu odniesienia, jednak, co ciekawe, patrzyły na niego znacznie częściej niż dzieci z grupy kontrolnej. Dzieci wiedziały więc, że mogą użyć punktu środkowego, ale nie były w stanie go zastosować w strategii lokalizacji liczby, której pozycję miały określić (zob. J.E. van't Noordende i in. 2016).

Kolejne badania pozwoliły na dokładniejsze zróżnicowanie strategii stosowanych przez dzieci dyskalkuliczne i dzieci, których poziom umiejętności matema- 
tycznych był odpowiedni (S. van Viersen i in. 2013). Testowano użyteczność strategii korzystania z punktu odniesienia. Badacze sprawdzili między innymi, czy dzieci używają punktu początkowego, aby zaznaczyć liczbę 18 na osi liczbowej przedstawiającej liczby z zakresu 0-100. Bezużyteczna strategia to używanie punktu odniesienia znajdującego się w dużym oddaleniu od szacowanej liczby. Okazało się, że dziewczynka, która zmagała się z dyskalkulią, używała w trakcie rozwiązywania tego zadania bezużytecznych strategii aż o 26\% częściej niż dzieci bez deficytów.

Prowadzono również badania testujące sposób, w jaki dzieci z dyskalkulią skupiają wzrok na osi liczbowej (W.D. Schot i in. 2015). Okazało się, że ich fiksacje były znacznie bardziej „rozrzucone” na osi liczbowej oraz zaobserwowano je dalej zarówno od liczby docelowej, jak i od odpowiedzi udzielanej przez grupę kontrolną. Wyniki te sugerują, że dyskalkulicy mają problem ze stosowaniem strategii szacowania miejsca liczby na osi.

Również w zadaniu ze zliczaniem kropek sprawdzano różnice w poprawności odpowiedzi udzielanych przez dzieci z dyskalkulią i grupę kontrolną (K. Moeller i in. 2009). Badanie to zostało zreplikowane przez P. Schleifer i K. Landerl (2011), jednak tym razem badacze skupili się nie tylko na poprawności odpowiedzi, ale także na ruchach oczu dzieci. Analiza okoruchowa wykazała, że uczniowie z dyskalkulią musieli liczyć kropki wiele razy, co odzwierciedla liczba fiksacji, która jest znacznie większa niż w przypadku normalnie rozwijających się dzieci. Dane te potwierdzają, że trudności w rozwiązywaniu podstawowych zadań niesymbolicznych wyłaniają się z deficytów na poziomie automatycznego i równoległego kodowania małych ilości przedstawionych w formatach niesymbolicznych.

\section{Dyskusja}

W niniejszym artykule zebrano dotychczasową wiedzę z zakresu diagnozowania dyskalkulii. Omówiono niektóre metody papierowe i komputerowe. Narzędzia te jednak skupiają się jedynie na obserwowanym poziomie umiejętności arytmetycznych. Z tego powodu zastosowanie eye-trackingu wydaje się być interesującym rozwiązaniem, ponieważ dostarcza informacji także o procesach leżących u podstaw przetwarzania liczb i pozwala na analizę poszczególnych etapów dochodzenia do rozwiązania w zadaniach matematycznych. Dane okulograficzne uzyskane z badań pomogły w zrozumieniu postrzegania cyfr i liczb wielocyfrowych oraz zależności przestrzennych między nimi. Dane z badań skupiających się na ruchach oczu w trakcie rozwiązywania zadań matematycznych pozwoliły na wyodrębnienie specyficznych ruchów oczu (P. Suppes i in. 1983) oraz zdefiniowanie strategii, którymi ludzie posługują się w trakcie liczenia (L. Kaufmann/ M. von Aster 2012). Badania porównujące strategie stosowane przez dorosłych i dzieci wykazały różnice w postrzeganiu zadań w tych dwóch grupach (K. Moeller/ E. Klein/ H. Nuerk 2011). Zastosowanie metody eye-trackingu pozwala również sprawdzić, jak rozwój kompetencji dziecka odzwierciedla jego znajomość osi liczbowej (M. Schneider i in. 2008). Badania (J. E. van't Noordende/ Kolkmann, 2013 za J.E. van't Noordende i in. 2016) z udziałem dzieci zmagających się z dyskalkulią wykazały różnice. Wiadomo między innymi, że dzieci z dyskalkulią znacznie częściej używają bezuży- 
tecznych strategii w zadaniach z szacowaniem pozycji liczby na osi liczbowej (S. van Viersen i in. 2013). Zestawienie razem powyższych wniosków, przekonuje do korzyści z zastosowania eye-trackingu przy diagnozowaniu trudności z matematyką. Dane okoruchowe pokazują, że szacowanie liczebności małych grup angażuje inne procesy niż zliczanie większej liczby elementów. Dostarczają one także wielu informacji na temat przetwarzania liczb i osi liczbowej u dyskalkulików. Dzięki kompleksowej analizie ruchów gałek ocznych można zrozumieć, w jaki sposób dzieci z trudnościami postrzegają liczby i na czym najbardziej skupiają się w trakcie rozwiązywania zadań. Dostrzeżenie różnic w tych procesach postrzegania między dyskalkulikami i osobami bez trudności jest kluczowe w zrozumieniu indywidualnych trudności z matematyką. Poczynione obserwacje mogą być pomocne przy opracowywaniu optymalnej terapii dostosowanej do potrzeb i deficytów dziecka.

\section{Bibliografia}

Adler, B. (2001). What is dyscalculia? Kognitivt Centrum Sweden.

Ardila, A./ M. Rosselli (2002), Acalculia and Dyscalculia, (w:) Neuropsychology Review, 12 (4), $179-231$.

Brysbaert, M. (1995), Arabic number reading: On the nature of the numerical scale and the origin of phonological recoding, (w:) Journal of Experimental Psychology, 124 (4), 434-452.

Butterworth, B. (2003), Dyscalculia Screener by Brian Butterworth. Highlighting pupils with specific learning difficulties in maths. Londyn.

Cangoz, B./ A. Altun/ S. Olkun/ F. Kacar (2013), Computer based screening dyscalculia: cognitive and neuropsychological correlates objects actions core knowledge social partners space number, (w:) The Turkish Online Journal of Educational Technology, 12 (3), 33-38.

Ceulemans, A./ D. Titeca/ T. Loeys/ K. Hoppenbrouwers/ S. Rousseau/ A. Desoete (2014), Enumeration of small and large numerosities in adolescents with mathematical learning disorders (w:) Research in developmental disabilities, 35 (1), 27-35.

Cohen, L./ S. Dehaene/ G. Dehaene-Lambertz (1998), Abstract representations numbers in the animal and human brain, (w:) Trends in Neurosciences, 21 (8), $355-361$.

Cipora, K. (2013), Czym jest liczba? (w:) Rocznik Kognitywistyczny, 6, 1-10.

Dackermann, T./ S. Huber/ J. Bahnmueller/ H.-C. Nuerk/ K. Moeller (2015), An integration of competing accounts on children's number line estimation, (w:) Frontiers in Psychology, 6, art 884.

Dehaene, S./ E. Dupoux/ J. Mehler (1990). Is Numerical Comparison Digital? Analogical and Symbolic Effects in Two-Digit Number Comparison, (w:) Journal of Experimental Psychology Human Perception \& Performance, 16 (3), 626-641.

Dehaene, S./ S. Bossini/ P. Giraux (1993), The Mental Representation of Parity and Number Magnitude, (w:) Journal of Experimental Psychology, 122 (3), 371 -396. 
Dehaene, S. (1996), The organization of brain activations in number comparison: Event-related potentials and the additive-factors methods, (w:) Journal of Cognitive Neuroscience, 8, 47-68.

Dehaene, S./ M. Piazza/ P. Pinel/ L. Cohen (2003), Three parietal circuits for number processing, (w:) Cognitive Neuropsychology, 3, 487-506.

Deheane, S./ L. Cohen (1995), Towards an anatomical and functional model of number processing, (w:) Science Open, 83-112.

Galton, F. (1880), Visualised Numerals, (w:) Nature, 15, 254 -256.

Geary, D.C. (1993), Mathematical disabilities: Cognitive, neuropsychological , and genetic components, (w:) Psychological Bulletin, 114, 345-362.

Geary, D.C./ M.K. Hoard (2001), Numerical and arithmetical deficits in learningdisabled children: Relation to dyscalculia and dyslexia, (w:) Aphasiology, 15 (7), 635-647.

Gielen, I./ M. Brysbaert/ A. Dhondt (1991), The syllable-length effect in number processing is task-dependent, (w:) Perception \& Psychophysics, 50 (5), 449458.

Guillemot, T. (2007), Dyscalculia - An Overview of Research on Learning Disability. Teacher Education Programme, (w:) Mathematics and Computing, 1-6.

Gut, M./ Ł. Goraczewski/ J. Matulewski (2016) Prokalkulia 6-9. Test oceny behawioralnych wskaźników umysłowych reprezentacji liczb i ryzyka dyskalkulii. Rotmanka.

Gut, M./ Ł. Goraczewski/ J. Matulewski/ K. Finc/ A. Ignaczewska/ B. Bałaj/ J. Dreszer/ M. Kmiecik/ J. Stępinska/ J. Majewski/ E. Bendlin/ P. Cholewa/ W. Duch. (2016). Trening poznawczy przy użyciu komputerowej gry matematycznej a przetwarzanie informacji numerycznej u dzieci - wyniki badań pilotażowych, (w:) M. Suchacka (red.) Cywilizacja zabawy, rozrywki i wypoczynku. Będzin, 89-126.

Hartmann, M./ F.W. Mast/ M.H. Fischer (2015), Spatial biases during mental arithmetic: evidence from eye movements on a blank screen, (w:) Frontiers in Psychology, 6, 1-8.

Isaacs, E. B./ C.J. Edmonds/ A. Lucas/ D.G. Gadian (2001), Calculation difficulties in children of very low birthweight, (w:) Brain, 124, 1701-1707.

Just, M. A./ P.A. Carpenter (1980), A theory of reading: From eye fixations to comprehension, (w:) Psychological Review, 87/ 4, 329-354.

Karpińska, E./ U. Sajewicz-Radtke/ B. M. Radtke (2014), Skala Gotowości Matematycznej i Ryzyka Dyskalkulii.

Kaufmann, L./ M. von Aster (2012), The Diagnosis and Management of Dyscalculia, (w:) Deutsches Ärzteblatt International, 109/ 45, 767-777.

Kolwer, E./ R. M. Steinmann (1979), Small saccades serve no useful purpose: reply to a letter by R. W. Ditchburn (w:) Vision research, 20, 273-276.

Kucian, K./ T. Loenneker/ T. Dietrich/ M. Dosch/ E. Martin/ M. Von Aster (2006). Behavioral and Brain Functions Impaired neural networks for approximate calculation in dyscalculic children: a functional MRI study, (w:) Behavioral and Brain Functions, 17, 1-17. 
Kucian, K./ G. Red/ C. Hospitals/ T. Loenneker/ T. Dietrich/ E. Martin (2008), Development of Neural Networks for Exact and Approximate Calculation: A fMRI Study, (w:) Developmental Neuropsychology, 33 (4), 447-473.

Kucian, K. / S. Schwizer Ashkenazi/ J. Hänggi/ S. Rotzer/ L. Jäncke/ E. Martin/ M. von Aster (2014) Developmental dyscalculia: a dysconnection syndrome? (w:) Brain Structure and Function, 5, (219), 1721-1733.

Landerl, K./ L. Kaufmann (2013), Dyskalkulia. Gdańsk.

Landy, D.H./ M.N. Jones/ R.L. Goldstone (2008), How the Appearance of an Operator Affects its Formal Precedence, (w:) Cognitive Science Society, 2109-2114.

Liang, X./ X. Shen/ D. Xiang/ J. Feng/ L. Lin/ S. Yan (2016) Semantic object parsing with local-global long short-term memory. Tekst zaprezentowany na konferencji Proceedings of the IEEE Conference on Computer Vision and Pattern Recognition w 2016 r.

Mazzeo J./ B. Druesne/ P. C. Rafleld/ K. T. Checketts/ A. Muhlstein (1991) Comparability of Computer and Paper-and-Pencil Scores for Two CLEP. General Examinations, Collage Entrance Examination Board. Nowy Jork.

Mazzocco, M.M.M./ R. E. Thompson (2005), Kindergarten Predictors of Math Learning Disability. Learning Disabilities Research \& Practice, 20 (3), 142-155.

McCrink, K./ S. Dehaene/ G. Dehaene-Lambertz (2007), Moving along the number line: Operational momentum in nonsymbolic arithmetic, (w:) Perception \& Psychophysics, 69 (8), 1324-1333.

Milosavljevic, M./ E. Madsen/ A. Rangel (2011), Fast saccades toward number : Simple number comparisons can be made in as little as $230 \mathrm{~ms}$, (w:) Journal of Vision, 11, 1-12.

Mock, J./ S. Huber/ E. Klein/ K. Moeller (2016), Insights into numerical cognition: considering eye-fixations in number processing and arithmetic (w:) Psychological research, 80 (3), 334-359.

Moeller, K./ M.H. Fischer/ H. Nuerk/ K. Willmes (2009), Eye fixation behaviour in the number bisection task: Evidence for temporal specificity, (w:) Acta Psychologica, 131 (3), 209-220.

Moeller, K/ E. Klein/ H.-C. Nuerk (2011), (No) Small Adults: Children's Processing of Carry Addition Problems (w:) Developmental neuropsychology, 36/6, 702-720.

Moeller, K./ H.-C. Nuerk, (2011). Psychophysics of numerical representation: why seemingly logarithmic representations may rather be multi-linear. Journal of Psychology. 219, 64-70.

Nosworthy, N./ S. Bugden/ L. Archibald/ B. Evans/ D. Ansari (2013), A Two-Minute Paper-and-Pencil Test of Symbolic and Nonsymbolic Numerical Magnitude Processing Explains Variability in Primary School Children's Arithmetic Competence (w:) Public Library of Science, 8 (7).

Nuerk, H. C./ K. Willmes (2005), On the magnitude representations of two-digit numbers Three models of two-digit magnitude representation, (w:) Psychology Science, 47 (1), 52-72.

Oszwa, U. (2006), Zaburzenia rozwoju umiejętności arytmetycznych. Problem diagnozy i terapii, Oficyna Wydawnicza Impuls. Kraków. 
Oszwa, U. (2008), Psychologia trudności arytmetycznych u dzieci. Doniesienia z badań. Kraków.

Parsons, S. (2006), British Cohort Study 2004 Follow Up Guide to Child Assessment Data November 2006. London.

Pinhas, M/ M.H. Fischer (2008), Mental movements without magnitude? A study of spatial biases in symbolic arithmetic, (w:) Cognition, 109 (3), 408-415.

Poltrock, S.E./ D.R. Schwartz (1984), Comparative judgments of multidigit numbers, (w:) Journal of Experimental Psychology. Learning, Memory, and Cognition, 10 (1), 32-45.

Przybylski, P./ U. Oszwa (2007), Zastosowanie testu figury złożonej Reya w różnicowaniu dysfunkcji poznawczych po uszkodzeniu płatów czołowych oraz płatów potylicznych i przyległych okolic kory, (w:) Postępy Psychiatrii i Neurologii, 16 (3), 201-209.

Pynte, J. (1974), Readiness for pronunciation during the reading process, (w:) Perception and Psychophysics, 16 (1), 110-112.

Rykhlevskaia, E./ L.Q. Uddin/ L. Kondos/ V. Menon (2009), Neuroanatomical correlates of developmental dyscalculia: combined evidence from morphometry and tractography, (w:) Frontiers in Human Neuroscience, 24, 3-51.

Schleifer, P./ K. Landerl (2011). Subitizing and counting in typical and atypical development. (w:) Developmental Science, 14 (2), 280-291.

Schneider, E. (2012), Eye gaze reveals a fast, parallel extraction of the syntax of arithmetic formulas, (w:) Cognition, 125 (3), 1-16

Schneider, M./ A. Heine/ V. Thaler/ J. Torbeyns/ B. De Smedt/ L. Verschaffel/ E. Stern (2008), A validation of eye movements as a measure of elementary school children's developing number sense, (w:) Cognitive Development, 23 (3), 424437.

Schot, W. D./ S. van Viersen/ J.E. van't Noordende/ E. Slot/ E.H. Kroesbergen (2015), Strategiegebruik op de getallenlijntaak geanalyseerd met behulp van eye-tracking, (w:) Pedagogische Studien, 92 (1), 55-69.

Shaki, S./ M.H. Fischer/ W.M. Petrusic. (2009), Reading habits for both words and numbers contribute to the SNARC effect, (w:) Psychonomic Bulletin \& Review, $16(2), 328-331$.

Siegler, R.S./ J.E. Opfer (2003), The development of numerical estimation: Evidence for Multiple Representations of Numerical Quantity, (w:) American Psychology Society, 14 (3), 237-243.

Song, J.-H./ Nakayama, K. (2008). Numeric comparison in a visually-guided manual reaching task, (w:) Cognition, 106, 994-1003.

Sophian, C./ M.E. Crosby. (2008) What Eye Fixation Patterns Tell Us About Subitizing, (w:) Developmental Neuropsychology, 33 (3), 394-409.

Spelke E.S./ S. Tsivkin (2001), Language and number: A bilingual training study, (w:) Cognition, 78, 45-88.

Suppes, P./ M. Cohen/ R. Laddaga/ J. Anliker/ R. Floyd (1983), A procedural theory of eye movements in doing arithmetic, (w:) Journal of Mathematical Psychology 27 (4), 341-369. 
Sullivan, J.L./ B.J. Juhasz/ T.J. Slattery/ H.C. Barth (2011), Adults' number-line estimation strategies: Evidence from eye movements, (w:) Psychological Bulletin. Review, 18, 557-563.

Tanenhaus, M.K. / M.J. Spivey-Knowlton/ K.M. Eberhard/ J.C. Sedivy (1995), Integration of visual and linguistic information in spoken language comprehension (w:) Science, 268 (5217), 1632-1634.

Yeo, K.K.J. (2006), Mathematical Problem-Solving Heuristics used by Secondary 2 Students, (w:) The Korean Journal of Thinking \& Problem Solving, 16 (2), 53-69.

van Viersen, S. / E.M. Slot/ A.H. Kroesbergen/ J.E. van't Noordende/ P.P. Leseman (2013), The added value of eye-tracking in diagnosing dyscalculia: A case study. (w:) Frontiers in Psychology, 4, 679.

van't Noordende, J. E./ A.H. van Hoogmoed/ W.D. Schot/ E. H. Kroesbergen (2016). Number line estimation strategies in children with mathematical learning difficulties measured by eye tracking. (w:) Psychological Research, 80 (3), 368-378.

Wiśniewska, B./ D. Hulewicz (2007), Dyskalkulia trudności w uczeniu się matematyki-problem, diagnozowanie, formy pomocy. 